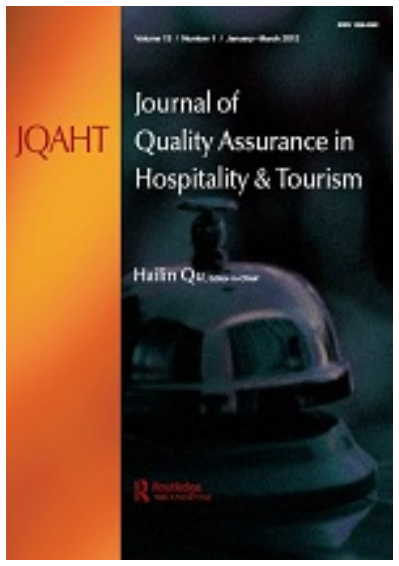

\title{
The impact of e-service quality on the customer satisfaction and consumer engagement behaviors towards luxury hotels
}

\begin{tabular}{|r|l|}
\hline Journal: & Journal of Quality Assurance in Hospitality \& Tourism \\
\hline Manuscript ID & WQAH-2019-0044.R3 \\
\hline $\begin{array}{r}\text { Keywords (pick from the list } \\
\text { OR enter your own): }\end{array}$ & $\begin{array}{l}\text { Original Article } \\
\text { E-service quality, hotel website }\end{array}$ \\
\hline & $\begin{array}{l}\text { Research background: Website quality of luxury hotels (from 4-star to 5- } \\
\text { star ranking) is a vital role to attract customer's first impression, } \\
\text { satisfaction, engagement behaviors, and loyalty intentions. } \\
\text { Purpose of the article: the study aims to increase the number online } \\
\text { bookers by boosting the level of customer satisfaction and customer } \\
\text { engagement behaviors (CEBs) on e-service of up-scale hotel websites in } \\
\text { Vietnam. Moreover, this study examines whether mediation relationships } \\
\text { between website quality, customer satisfaction, and CEBs. } \\
\text { Methods: the 332 online bookers fulfilled the survey via online and } \\
\text { offline approaches. The PLS-SEM analysis applied to measure the } \\
\text { relationship of the constructs. } \\
\text { Findings: The study confirms that website service quality contributes to } \\
\text { customer satisfaction, then influences their CEBs and brand loyalty. } \\
\text { Additionally, customer satisfaction acts as a partial mediation on the } \\
\text { relationships between hotel website service quality and CEBs in the hotel } \\
\text { industry. } \\
\text { Originality/Value added: besides the results of the new insights of hotel } \\
\text { website studies, this research is one of the pioneering studies } \\
\text { concentrating on the impact of consumer engagement behaviors on its } \\
\text { site, satisfaction and loyalty intention in the hotel and tourism industry. } \\
\text { The study supports the business of e-commerce and operation of } \\
\text { hotel/tourism service, marketing and research. }\end{array}$ \\
\hline Abstraction
\end{tabular}

\section{SCHOLARONE" Manuscripts}


56

57

58

59

60

URL: http://mc.manuscriptcentral.com/jqaht Email:hmhanqin@polyu.edu.hk 


\section{The impact of e-service quality on the customer satisfaction and consumer} engagement behaviors towards luxury hotels

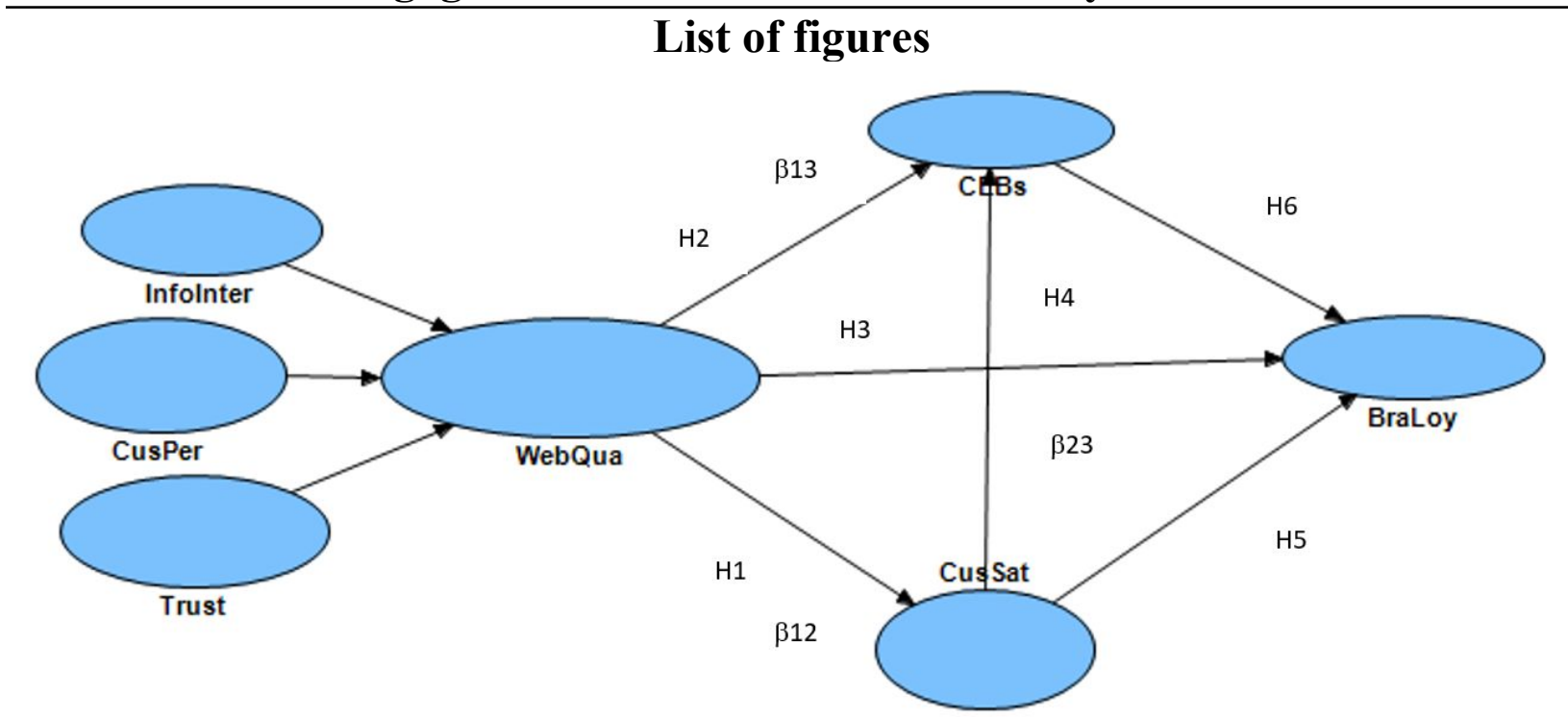

Figure 1. The research model and the proposed relationships

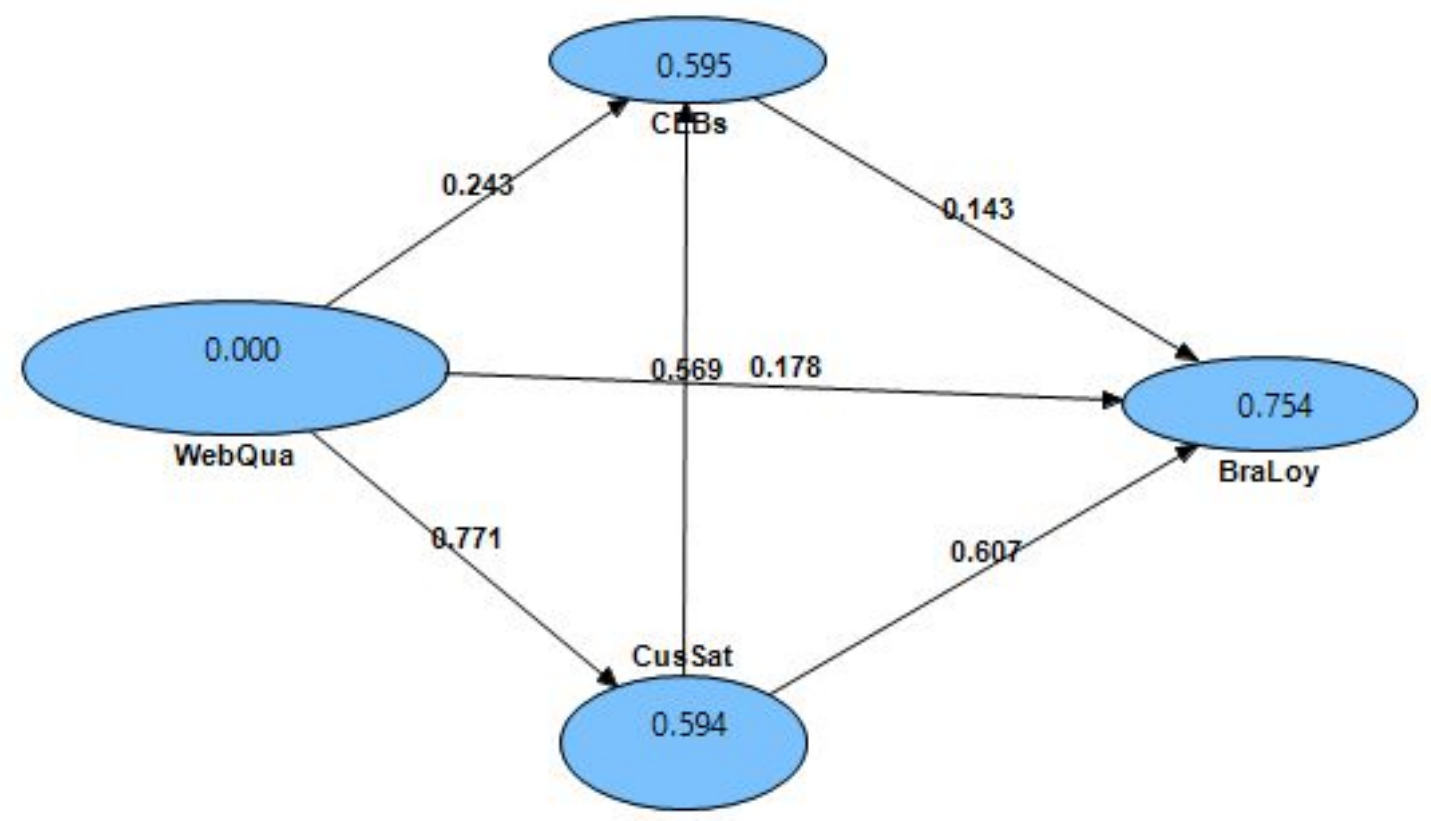

Figure 2. Structural model of second-order construct 


\section{The impact of e-service quality on the customer satisfaction and consumer engagement behaviors towards luxury hotels}

\section{List of tables}

\section{Table 1. Key references of construct based on reflective indicators}

\begin{tabular}{|c|c|c|}
\hline & Customer perception of hotel website & Key references \\
\hline CP1 & The hotel website quality meets positively one' demands & (Liu \& al, 2013) \\
\hline $\mathrm{CP} 2$ & $\begin{array}{l}\text { The performance of website can be attributed to its features and } \\
\text { elements }\end{array}$ & $\begin{array}{l}\text { (Musante, Bojanic, \& Zhang, } \\
\text { 2009) }\end{array}$ \\
\hline \multirow[t]{2}{*}{$\mathrm{CP} 3$} & $\begin{array}{l}\text { My perception of hotel website quality could impact on my behaviors } \\
\text { at first interaction with website }\end{array}$ & $\begin{array}{l}\text { (Jiang, Wang, Tan, \& Yu, } \\
\text { 2016) }\end{array}$ \\
\hline & Information and Interface & Key references \\
\hline III & The hotel website quality is security & (Dolatabadi \& Pool, 2013) \\
\hline II2 & The hotel website quality is enjoyment & (Hasanov, 2015) \\
\hline II3 & The information is hotel website quality & (Jeong, Oh, \& Gregoire, 2003) \\
\hline \multirow[t]{2}{*}{ III } & The hotel website quality is ease of use & (Hasanov, 2015) \\
\hline & Trust & Key references \\
\hline T1 & The hotel website is reliable & (Everard \& Galletta, 2014) \\
\hline $\mathrm{T} 2$ & I consider to take risk of booking on hotel website & (Mukherjee \& Nath, 2007) \\
\hline \multirow[t]{2}{*}{$\mathrm{T} 3$} & I'm ready to commit to purchase the service on hotel website & (Morgan \& Hunt, 1994) \\
\hline & The service quality (SQ) & \\
\hline SQ1 & The quality of website is service & $\begin{array}{l}\text { (Li L., Penga, Jiang, \& Law, } \\
\text { 2017) }\end{array}$ \\
\hline SQ2 & Price presentation on website of hotel and OTAs is the same & (Noone \& Mattila, 2009) \\
\hline SQ3 & I'm satisfied to reserve a room on website of hotel & $\begin{array}{l}\text { (Loiacono, Watson, \& } \\
\text { Goodhue, 2002) }\end{array}$ \\
\hline \multirow[t]{2}{*}{ SQ4 } & The service of website is useful & (Bai, Law, \& Wen, 2008) \\
\hline & Consumer Engagement Behaviors (CEBs) & \\
\hline CEB1 & I would purchase and repurchase service on hotel website & developed by the authors \\
\hline CEB2 & I would switch to other hotel & \\
\hline CEB3 & I would ask for refund of room booking with the hotel & \\
\hline \multirow[t]{2}{*}{ CEB4 } & I would recommend the hotel website with others & \\
\hline & Brand Loyalty (BL) & 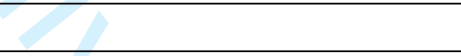 \\
\hline BL1 & I am willing to pay more for a booking on hotel website & $\begin{array}{l}\text { (Ribbink, Riel, Liljander, \& } \\
\text { Streukens, 2004) }\end{array}$ \\
\hline BL2 & I rely on website to book a room & $\begin{array}{l}\text { (Harrigan, Evers, Miles, \& } \\
\text { Daly, 2017) }\end{array}$ \\
\hline \multirow[t]{2}{*}{ BL3 } & The hotel website provides me more benefits for booking & $\begin{array}{l}\text { (Guo, Zheng, Ling, \& Yang, } \\
\text { 2014) }\end{array}$ \\
\hline & Customer Satisfaction (CS) & \\
\hline CS1 & I am satisfied with hotel website & (Bai, Law, \& Wen, 2008) \\
\hline $\mathrm{CS} 2$ & I continue to use booking service on hotel website & (Hung, 2017) \\
\hline CS3 & I am positively associated myself with the hotel' e-service & (Zhao, Xu, \& Wang, 2018). \\
\hline
\end{tabular}




\section{Table 2. Demographic profile of respondents}

$$
\mathrm{N}=321 \quad \%
$$

Gender

Female

$201 \quad 60.5$

Male

39.5

Age bracket

$18-25$

131

25.9

25-35

$36-45$

$78-25.9$
127

$>45$

127

42.2

$84 \quad 27.9$

$12 \quad 4.0$

Daily Internet usage

$<4 \mathrm{hrs}$

21.9

4-8hrs

44.2

$>8 \mathrm{hrs}$

$\begin{array}{rr}66 & 4.9 \\ 133 & 44.2 \\ 102 & 33.9\end{array}$

Working experience

$<1$ year

$30 \quad 10.0$

1-3 years

$54 \quad 17.9$

3-5 years

$\begin{array}{ll}30 & 10.0\end{array}$

5-10 years

$85 \quad 28.2$

$>10$ years

102

33.9

Personal monthly income

$<\$ 500$

$83 \quad 25.0$

$\$ 500-\$ 1000$

$127 \quad 38.3$

$\$ 1000-\$ 1500$

$\begin{array}{ll}52 & 15.7\end{array}$

$\$ 1500-\$ 2000$

28

8.4

$\$ 2000-\$ 5000$

31

9.3

$\$ 5000-\$ 10000$

$>\$ 10000$

7

2.1

Education

Vocational College

Bachelor Degree

$24 \quad 8.0$

Post Graduate

108

35.9

Booking intention on hotel website

Yes

$169 \quad 56.1$

No

$207 \quad 62.3$

$125 \quad 37.7$

Table 3. Validity and reliability of the constructs

\begin{tabular}{|l|l|l|l|l|}
\hline $\begin{array}{l}\text { Constructs and } \\
\text { items }\end{array}$ & & Loadings & AVE & CR \\
\hline $\begin{array}{l}\text { Customer } \\
\text { perception }\end{array}$ & $\mathrm{CP} 1$ & 0.9073 & & 0.9097 \\
\cline { 2 - 3 } & $\mathrm{CP} 2$ & 0.9187 & 0.7212 & \\
\hline
\end{tabular}




\begin{tabular}{|c|c|c|c|c|}
\hline & $\mathrm{CP} 3$ & 0.8037 & & \\
\hline \multirow{4}{*}{$\begin{array}{l}\text { Information \& } \\
\text { Interface }\end{array}$} & III & 0.8254 & \multirow[b]{4}{*}{0.7963} & \multirow{4}{*}{0.9197} \\
\hline & II2 & 0.896 & & \\
\hline & II3 & 0.9237 & & \\
\hline & II 4 & 0.9206 & & \\
\hline \multirow{3}{*}{ Trust } & $\mathrm{T} 1$ & 0.8391 & \multirow[b]{3}{*}{0.721} & \multirow{3}{*}{0.9096} \\
\hline & $\mathrm{T} 2$ & 0.9297 & & \\
\hline & $\mathrm{T} 3$ & 0.9442 & & \\
\hline \multirow{4}{*}{ Service quality } & SQ1 & 0.7325 & \multirow[b]{4}{*}{0.6999} & \multirow{4}{*}{0.8744} \\
\hline & $\begin{array}{l}\text { SQ2 } \\
\text { (exclude) }\end{array}$ & -0.4827 & & \\
\hline & SQ3 & 0.8887 & & \\
\hline & SQ4 & 0.8445 & & \\
\hline \multirow{4}{*}{$C E B s$} & CEB1 & 0.8141 & \multirow[b]{4}{*}{0.5806} & \multirow{4}{*}{0.8393} \\
\hline & CEB2 & 0.787 & & \\
\hline & CEB3 & 0.5774 & & \\
\hline & CEB4 & 0.8166 & & \\
\hline \multirow{3}{*}{ Brand loyalty } & BL1 & 0.68 & \multirow[b]{3}{*}{0.6634} & \multirow{3}{*}{0.8538} \\
\hline & BL2 & 0.8935 & & \\
\hline & BL3 & 0.8541 & & \\
\hline \multirow{3}{*}{$\begin{array}{l}\text { Customer } \\
\text { satisfaction }\end{array}$} & $\mathrm{CS} 1$ & 0.9309 & \multirow[b]{3}{*}{0.7211} & \multirow{3}{*}{0.9095} \\
\hline & $\mathrm{CS} 2$ & 0.8856 & & \\
\hline & $\mathrm{CS} 3$ & 0.9271 & & \\
\hline
\end{tabular}

Table 4. Discriminant validity

\begin{tabular}{|c|c|c|c|c|c|c|c|}
\hline \multicolumn{8}{|c|}{ Fornell and Larcker's (1981) } \\
\hline & 1 & 2 & 3 & 4 & 5 & 6 & 7 \\
\hline \multicolumn{8}{|l|}{ 1.BraLoy } \\
\hline 2.CEBs & 0.7235 & & & & & & \\
\hline 3.CusPer & 0.6317 & 0.6259 & & & & & \\
\hline 4.CusSat & 0.8526 & 0.7559 & 0.6417 & & & & \\
\hline 5.InfoInter & 0.4822 & 0.4629 & 0.7694 & 0.53 & & & \\
\hline 6.Trust & 0.5108 & 0.5089 & 0.6724 & 0.6454 & 0.8022 & & \\
\hline 7.WebQua & 0.7419 & 0.6823 & 0.6734 & 0.7708 & 0.4575 & 0.6054 & \\
\hline \multicolumn{8}{|c|}{ Heterotrait-monotrait (HTMT) } \\
\hline 1.BraLoy & 0.814494 & & & & & & \\
\hline 2.CEBs & 0.7233 & 0.761971 & & & & & \\
\hline 3.CusPer & 0.6328 & 0.6271 & 0.849235 & & & & \\
\hline 4.CusSat & 0.8525 & 0.7561 & 0.6429 & 0.8491761 & & & \\
\hline 5.InfoInter & 0.4836 & 0.4634 & 0.7679 & 0.5306 & 0.892356 & & \\
\hline 6.Trust & 0.5107 & 0.5092 & 0.6722 & 0.6453 & 0.8008 & 0.849117 & \\
\hline 7.WebQua & 0.7472 & 0.6921 & 0.6525 & 0.7879 & 0.4497 & 0.5831 & 0.836600263 \\
\hline
\end{tabular}


Table 5. Weights of the first order constructs on the designated second-order constructs

\begin{tabular}{llrr}
\hline $2^{\text {nd }}$ order construct & 1 Wt-order constructs & Weight & \multicolumn{1}{c}{ t-value } \\
\hline & Customer Perception of hotel website & .741 & $14.182 *$ \\
& Information and Interface of hotel website & -.607 & -9.177 \\
Hotel website quality & Trust on hotel website & .626 & $10.684^{*}$ \\
& & & \\
& Note: t-values. $* 2.58(\mathrm{P}<0.01)$ & & \\
\hline
\end{tabular}

\section{Table 6. Testing of hypotheses testing}

\begin{tabular}{lllll}
\hline Hypotheses & R Square & Beta & t-value & Decision \\
\hline H1: Service quality --> Customer satisfaction & 0.754 & 0.004 & $13.841^{*}$ & Supported \\
H2: Service quality --> CEBs & 0.595 & 0.049 & $2.226^{* *}$ & Supported \\
H3: Service quality --> Brand loyalty & 0.594 & 0.075 & 1.538 & Not Supported \\
H4: Customer satisfaction --> CEBs & 0.569 & 0.041 & $3.7252^{*}$ & Supported \\
H5: Customer satisfaction --> Brand loyalty & 0.607 & 0.030 & $4.5084^{*}$ & Supported \\
H6: CEBs --> Brand Loyalty & 0.143 & 0.088 & 1.2753 & Not Supported \\
Note: Critical t-values. ${ }^{*} \mathrm{p}<.01 . * * \mathrm{p}<.05$. & & & & \\
\hline
\end{tabular}




\title{
The impact of e-service quality on the customer satisfaction and consumer engagement behaviors towards luxury hotels
}

\author{
Nga Thi Vo \\ Economics and Management Faculty, Tomas Bata University in Zlin, Czech Republic. \\ (based by Hoa Sen University, Tourism Faculty, Vietnam) \\ ngavongoc789@gmail.com; \\ Miloslava CHOVANCOVÁ \\ Economics and Management Faculty, Tomas Bata University in Zlin, Czech Republic \\ chovancova@utb.cz

\section{Ho Thanh TRI} \\ Economics and Management Faculty, Tomas Bata University in Zlin, Czech Republic \\ hothanhtri@gmail.com
}




\section{Abstract:}

Research background: Website quality of luxury hotels (from 4-star to 5-star ranking) is a vital role to attract customer's first impression, satisfaction, engagement behaviors, and loyalty intentions.

Purpose of the article: the study aims to increase the number online bookers by boosting the level of customer satisfaction and customer engagement behaviors (CEBs) on e-service of up-scale hotel websites in Vietnam. Moreover, this study examines whether mediation relationships between website quality, customer satisfaction, and CEBs.

Methods: the 332 online bookers fulfilled the survey via online and offline approaches. The PLSSEM analysis applied to measure the relationship of the constructs.

Findings: The study confirms that website service quality contributes to customer satisfaction, then influences their CEBs and brand loyalty. Additionally, customer satisfaction acts as a partial mediation on the relationships between hotel website service quality and CEBs in the hotel industry.

Originality/Value added: besides the results of the new insights of hotel website studies, this research is one of the pioneering studies concentrating on the impact of consumer engagement behaviors on its site, satisfaction and loyalty intention in the hotel and tourism industry. The study supports the business of e-commerce and operation of hotel/tourism service, marketing and research.

Keywords: brand loyalty, customer engagement behaviors, customer satisfaction, e-service quality, hotel website

\section{JEL Classification: O10, O53, P22, P36}

\section{Introduction}

Following the progress of online markets, hotel and tourism industries have quickly transformed the e-commerce from the goal of understanding the market to influencing the customers' choices by advanced information technology. Through integrating the business processes and anticipating consumer engagement behaviors, then responding quickly to the market targeted to exploit opportunities that present brand names. Three out of four billion users around the world access the internet on mobile devices to associate with social media monthly (McDonald, 2018). The progress in website evaluation has analyzed the practitioners and researchers to have forward works (Law R. Q., 2010). Because of the integration of hotels, the travel and tourism market has been adopted internet such a significant role (Collins, 2013), which obtains its side-effects on business. This study is conducted to stimulate purchase intention, engagement behaviors and satisfaction levels of online users towards the context of hotel and tourism service (Amaro \& Duarte, 2015). Practically, the online revenue of travel booking segment in 2018 earned US\$345,567mil, in which hotel revenue got to US\$142,013m (Statista, 2018). Partly under the hotel context in Vietnam, hotel rooms earned US\$493mil out of US\$671mil (Statistica, 2018) and 48\% of online users search for hotel destinations (Vietnamnews, 2017). Accordingly, the online channel becomes effective communication with its customers (Díaz \& Koutra, 2013). Nevertheless, commercial transactions are not only convenient, economic cost, and product diversity (Yoon, 2002) but also influenced by perceived value and trust (Ponte, Carvajal, \& Rodriguez, 2015). Furthermore, the principal characteristics of website quality impact customer satisfaction, purchase intention and 
behavior (Hsu, Chang, \& Chen, 2012). Especially, the hotels are from 4-star to 5-star ranking will perform better than lower star rating hotels (Leung, Law, \& Lee, 2016).

One of the most significant online contacts between customers and hoteliers is the hotel website. It was the emergence ITs and innovative management method of hotel service quality to fill the interconnection gaps in the social media channel to improve its competitiveness (Buhalis D. , 1998). The information, interface, and trustworthy facts and details (Ahmad \& Sun, 2018) showed on the hotel website and social media can influence online bookers (Ferguson, 2014) and direct customer decision making (Martín \& Herrero, 2012). In the long run, the hotel website's interactivity could motivate users to reload the hotel website (Abdullaha, Jayaraman, \& Kamal, 2016). Regarding from different types of hotels (i.e. international tourist hotels, ordinary hotels, 4-star and 5-star hotels) the content of websites directly has influenced customer preferences and decisions (Ting, Kuo, \& Li, 2012). Therefore, hotel and travel suppliers could rely on this 'must-have' distribution channel to reach the customer and sell products without paying commission for third parties such as online travel agencies and travel companies (Ling, Dong, Guo, \& Liang, 2015). In addition, the e-service quality strongly impacts on customer satisfaction and loyalty as a capable predictor (Ho \& Lee, 2007). In return for online commerce, customers got lower prices and time savings (Vincent, 2003). Furthermore, social media could afford for customer engagement in tourism (Cabiddu, Carlo, \& Piccoli, 2014). The customer engagement enhanced customers' service, especially brand loyalty (So K. , King, Sparks, \& Wang, 2014) for both hotel and airline customers (So, King, \& Sparks, 2012). Customer engagement in luxury hotels in India contributes to higher hotel customer loyalty (Rather \& Sharma, 2017). However, there were numerous barriers towards successfully engaging consumers, technology and strategic cases (Chathoth, et al., 2014) in both tourism and non-tourism contexts (Harrigan, Evers, Miles, \& Daly, 2017). The customer engagement effects directly on tourists' satisfaction and loyalty in Malaysia (Rasoolimanesh, Md Noor, Schuberth, \& Jaafar, 2019). Besides, Fishbein \& Ajzen (1970) explored the Theory of Reasoned Action (TRA) for correlation between behaviors and attitudes within human actions and TRA has been redefined antecedents of unit brand loyalty to confirm that consumers are brand loyal when behaviors and attitudes are attached (Ha, 1998). The finding is inclined with this study, but they likely propose models to take advantages of understanding customer intentions to purchase travel online. Despite numerous previous researches into inherent hotel website quality, there is a lack of study of the correlation between customer satisfaction and consumer engagement behaviors (CEBs) for loyalty in a competitive positioning to adopting such an approach in the context of the Vietnam tourism market from 4-star to 5-star hotels.

Hence, regarding the preceding discussion, understanding the effect of website quality' attributes is in need to enhance levels of customer satisfaction, engagement behaviors and loyalty to the brand. The findings will help online travel suppliers to better understanding luxury hotel users' behaviors. Getting to know the driving force effect website quality to satisfy and engage customers or into convert lookers to buyers and repeated guests on the online platform of luxury hotels. The remained content is made in the following ways: reviewing of literature, collecting data via online and offline approaches, examining data analysis by PLS-SEM, presenting results and discussion, proposing implication and further research

\section{Literature review}

2.1 The links of e-service quality of hotel website with customer satisfaction, CEBs and brand loyalty

According to Li et al. (2017), the hotel website is defined such e-service quality by online lookers and investigated its factors; and is perhaps one of the important way to communicate with its 
customers in the online platform (Chen \& Dhillon, 2003) especially at the pre-purchase phase. The overall performance of a website service is evaluated by online users, named hotel website quality (Aladwani \& Palvia, 2002). Good quality is essential for the service standard of the hotel (Li, Ye, \& Law, 2013). The concept of e-service in "website quality" is mentioned in different industries and positively influences the marketing performance and e-service (Liu, Arnett, \& Litecky, 2000). The price presentation on the OTAs site and hotel website approach are likely the same (Noone \& Mattila, 2009). A website provides venue' information for lookers (Jeong, Oh, \& Gregoire, 2003) with its vital functionality (Ip C. L., 2012) for room booking details (Ma A. L., 2008). For example, a hotel website is such a mass media channel (Schmidt, Cantallops, \& Santos, 2008), a first touch with customers (Jiang, Wang, Tan, \& Yu, 2016). Moreover, it has a positive influence on customer satisfaction (Bai, Law, \& Wen, 2008) in order to satisfy customers' needs (Loiacono, Watson, \& Goodhue, 2002), to encourage customer for next visit on hotel website (Abdullaha, Jayaraman, \& Kamal, 2016) and to put effective management together in the online business (Bauer, Hammerschmidt, \& Falk, 2005). However, the customers' benefits and requirements have not been fulfilled to highlight the crucial role of the website in the hotel and tourism business (Law \& Leung, 2000). Some websites ignore their interactivities with customers before the sale transaction (Schmidt, Cantallops, \& Santos, 2008). From among the hotel users' perspective, the content-rich and user-friendly websites have no significant difference (Hsu \& Cathy, 2005). The content is King. To what extent the hotel describes rooms or rate plans would help guests make the decision. For instance, (1) the description of room is able to provide the lookers with the built-up, maximum number of guests, bed configuration, extra bed options, the window view or balcony; (2) the detail of rate plans can boost customer to book the room due to its benefits of selection; and (3) there are $77 \%$ of consumer booking decisions being influenced by available amenities (TripAdvisor). In other words, the content of the website could set the hotel apart from its competition, in turn, affects on levels of lookers' engagement, satisfaction, and loyalty (Rasoolimanesh, Md Noor, Schuberth, \& Jaafar, 2019).

Furthermore, within the stimulus-organism-response paradigm, the authors argued that the website quality dimension is described by customers as less likely important compared to a website brand (Chang \& Chen, 2008). The hotel website needs to build a trusting relationship with the customer (Wang, et al., 2015). Consequently, promoting online purchases will soon be an issue that is the core function of a hotel website (Hung, 2017). The study of a convenience sample of 50 university students across two developed (USA and Australia) and two developing economies (India and China) examined the different types of CEBs towards service. The researchers show that service providers need to treat customers fairly to heighten positive CEBs (Roy, Balaji, Soutar, Lassar, \& Roy, 2018). However, previous work has failed to address the contribution of customer cognition of website service quality in improving the levels of customer satisfaction and especially CEBs. The dynamic perspective of online users can lead the right track of the hotel website. Jiang et al. (2016) said that how customers define website quality could impact their behaviors due to the first interaction with website service. The customer perception here may be made up with various dimensions by users (Hsu \& Cathy, 2005) included opinions and sentiment (Li, Ye, \& Law, 2013), and service demands from the study of Liu et al. (2013). Overall, the features and elements of a website could classify its performance (Musante, Bojanic, \& Zhang, 2009). However, some hotel websites only served searchers such a reservation channel (Ma A. L., 2008), lack of personalized interaction and ways of account payment online (Chang \& Chen, 2008) which indirectly influenced behavioral consequences of customer satisfaction (Belanche, 2012). Because of the higher hotel star rating, the higher the customer expectation for website performance (Salavati \& Hashim, 2015). Consequently, the neglected area in the field of this study will be tapped to explore the causal effect of perceived e-service quality on CEBs. 
A website needs to maintain effective and efficient information and interface. Especially Information communication technology (ICT) is used in the tourism industry for online transactions (Kim M. J., 2011). It is such one of the mixed motives for joining the global business: a desire to make use of ICT, but also a desire to decrease uncertainty expectation. There is prevalent growth in shopping tourism products/services online, named online travel agencies (OTAs) such as Agoda, Expedia, Travelocity, and Orbitz (Chen C. , 2006). The OTAs maintained powerful marketing and operational tool for the internet to enhance extraordinary chances to sell products for the hotel and tourism business (Amaro \& Duarte, 2015) and bridge the gap of distribution channels between suppliers and consumers (Ponte, Carvajal, \& Rodriguez, 2015). The web design features are important for online relationship marketing (Bilgihan \& Bujisic, 2014). Because a hotel website quality is information quality (Jeong, Oh, \& Gregoire, 2003) with its crucial role (Ip C. L., 2012) like a reservation information (Ma A. L., 2008), a mass media channel (Schmidt, Cantallops, \& Santos, 2008) to enhance social identification and social exchange to build customer loyalty (Rather \& Hollebeek, 2019). However, these sites decrease the access of users to reach a hotel website. Whenever lookers search for accommodation service or particular hotel address, the Metasearch engine (e.g. Google, MSN Search, Yahoo, etc.) can list the ads and OTAs sites on the first page, except the users key in the right hotel website address. So hotels depend on OTAs channel to spread information at first and put services on the market. Hotel website must develop its site' functionality (Bauer, Hammerschmidt, \& Falk, 2005), creativity (Bevanda, Grzinic, \& Cervar, 2008), enjoyment and ease of use (Hasanov, 2015), privacy, security and accessibility (Dolatabadi \& Pool, 2013).

Those attempts have seen such a competitive advantage in the e-commerce industry for customers' experiences (Zeng, 2012) and satisfaction positively (Bai B. L., 2008). Grant Thornton reported that $67.3 \%$ of the hotels in Vietnam in 2015 integrated digital technology to online service and mobile devices. So there should be balance the service and information technology of the website (Nath \& Singh, 2010). Nevertheless, online users on up-scale hotel markets expect to use a website system without effort (Davis, 1989). Otherwise, they found distrust information and dissatisfy the service providers (Chathoth, 2007), unfriendly interface (Pranic'1, 2014); or ineffective management (Hsieh, 2012). Consequently, the information on hotel booking sites has been an imperative consideration for online users (Gavilan, Avello, \& Navarro, 2018). Therefore, an online presence is a vital role to optimize its website quality to maximize benefits for customers and suppliers.

What makes a long relationship between buyers and sellers? Perhaps it is to trust each other. Especially in the online platform, trust is countable for reliability and dependability (Everard \& Galletta, 2014) in the individual perspective of CEBs (Roy S. K., 2018). Corritore et al. (2003) mentioned that e-trust is a confident expectation of one's attitude and willingness without online risks to appreciate the level of confidence in its partner's cooperative behavior. It is therefore necessary to look at them in the management and to be successful relationship marketing towards commitment and trust, even though it was considered as risk-taking behavior and its consequences (Mukherjee \& Nath, 2007) directly positively affect room booking online by Li et al. (2017) and loyalty from study of Ribbink et al. (2004). Trust could build long-term relationships with customers in the service industry and from then on direct customers' attention to repurchase service on a hotel website (Abdullaha, Jayaraman, \& Kamal, 2016). However, some viewers did distrust comments and information via website (Ahmad \& Sun, 2018) or hesitate to buy service if they feel risky or uncertainty (McKnight, Choudhury, \& Kacmar, 2002). Lien et al. (2015) preferred to book rooms on OTA channels such as Agoda, Booking, TripAdvisor, etc. because of its convenience and quality assurance (Rahimnia, 2013). So, the future of e-commerce may depend on trust (Wang \& Emurian, 2005). Nevertheless, some researchers believed that trust has a positive 
influence on purchase travel online (Amaro \& Duarte, 2015) (Wen, 2010). However, some researchers argued that it effect indirectly the way of booking online (Kamarulzaman, 2007). Wang et al. (2015) argued that trust is such a mediator to influence service quality of the hotel website when perceived risk (Chang \& Chen, 2008). Consequently, to the best of our knowledge, it is argued that trust has a positive impact on the website service quality towards luxury hotels. Therefore, as the intention is determined by luxury hotel users towards the website quality service and it is hypothesized as follows:

H1. Customer cognition of hotel website service quality (including customer cognition of hotel website, information and interface, and trust) affects customer satisfaction

H2. Customer cognition of hotel website service quality (including customer cognition of hotel website, information and interface, and trust) effects CEBs

H3. Customer cognition of hotel website service quality (including customer cognition of hotel website, information and interface, and trust) affects brand loyalty

2.2 The links of Customer satisfaction via e-service quality with CEBs and Brand loyalty.

Regarding the marketing aspects of consumer expectations and actual performance, customer satisfaction is measured by the customer's subjective evaluation of a product/service (Anderson, Fornell, \& Lehman, 1994). Because satisfaction is the essential goal to strive for the consumer marketing community (Oliver, 1999), to encourage customers to return, give comments, recommend to their friends to increase relationship of customers with the hotel industry (Rather R. A., 2017) and to affect customers' behavioral loyalty in return (Wang, Lawa, Guillet, Hung, \& Fong, 2015) (Gavilan, Avello, \& Navarro, 2018). In the e-commerce, customer satisfaction was inclined with e-service quality (Bai, Law, \& Wen, 2008) such as information system (Liu, Arnett, \& Litecky, 2000) (Jeong, Oh, \& Gregoire, 2003) guest comments (Zhao, Xu, \& Wang, 2018).

In the mix hotel ranking ('luxury', 'upscale' or 'mid-market'), website quality gets indifferent significance (Yeung \& Law, 2006) but its functionality such as "Reservation" (Ip, Law, \& Lee, 2012) directed customer's purchase intention (e.g. in Taiwan) (Hung, 2017), in tourist' destinations (i.e. in India) (Rather A. R., 2018) and usage (Ma, Law, \& Ye, 2008). Those factors could establish the success of the hotel website. However, there seems to be a widespread agreement that website quality affects the level of customer satisfaction. A study of Rather et al. (2019) have explored the causes and effects of CEBs on tourists (Rather, Hollebeek, \& Islam, 2019), and effect of customer intention of loyalty on customer satisfaction and CEBs (Rather, Tehseen, Itoo, \& Parrey, 2019). It is expected that the higher the star rating of the hotel, the higher website quality should live up to customer expectation. In this study website quality of 4-star and 5-star hotels are defined as luxury "...has to appear the best of whatever it represents to deliver the brand's name promise.." Isadore Sharp (CEO in Four Seasons Hotels \& Resorts) said; "something unique, beyond customer expectations to fill their needs and wants" Carrie McDougall said (President in Cultural Crossroads). The representativeness of 240 Indian guests in 4 and 5star hotels resulted that the customer engagement contributes relationship to hotel customer loyalty (Rather \& Sharma, 2017). A study through a convenience sample of 345 consumers on luxury hotels resulted that the customer satisfaction positively impacts loyalty (Rather \& Hollebeek, 2019). The influence of customer perception of brand might play a role in hotel brand loyalty (Rather, 2018). Hence, the following hypotheses are proposed:

H4. Customer perceived satisfaction via e-service quality affects CEBS

H5. Customer perceived satisfaction via e-service quality effects brand loyalty

2.3 The relationship of CEBs and brand loyalty

Brodie et al. (2011) defined CEBs as a psychological state when interact with customer experiences within specific service relationships. CEBs are as motivational drivers of customer's behavioral on a brand focus beyond purchase such as complaint, ask for an apology, request for 
refund and improve the product/service (Doorn, et al., 2010). For example, hotel guests would purchase and repurchase service on the hotel website if they are over-joyful with the e-service quality of the hotel. CEBs are engaged in the service context (Islam, Hollebeek, Rahman, Khan, \& Rasool, 2019).

In the concept of marketing and corporate performance in today's interactive and dynamic business environments, getting to know CEBs is vital to attract, purchase/repurchase, and exhibit greater loyalty to focal brands (Hollebeek, 2010). However, there are in need to explore the consequences of CEBs with marketing service (Rather, 2019) and customer brand in hotels/resort (Ahn \& Back, 2018). Additionally, So et al. (2014) and Harrigan et al. (2017) confirmed that hotel and tourism management on social sites should have better assess the nature of customer engagement to boost trust on brand loyalty. Rather et al. (2018) promoted customer engagement and brand loyalty through their identification and value congruity (Rather, Tehseen, \& Parrey, 2018). However, some authors argued that the conceptualization of CEBs needs more focus on psychological and behavioral attributes. For examples, CEBs needs to take into account the role of commitment, involvement and trust (Bowden, 2014); engagement, telepresence and interactivity in online consumer experience (Mollen \& Wilson, 2010); and networked society through social networks in between users and providers (Verhoef, Reinartz, \& Krafft, 2010).

The website is evaluated by 4Ps (Product, Promotion, Price, Place) and added the role of customer relationship (Chiou, Lin, \& Perng, 2011). Using PLS-SEM analysis, the authors said that tourist engagement shows a strong positive effect on tourists' satisfaction and loyalty in the Kinabalu National Park, Malaysia (Rasoolimanesh, Md Noor, Schuberth, \& Jaafar, 2019). Therefore, the meaning of the relationship between customer engagement and the tourism service industry (Cheung, Lee, \& Jin, 2011) in the visual analytic approach (Cheng, 2015) cannot be ignored recently (Cabiddu F. C., 2014). Outputs were enhancing the engagement of buyers and sellers for effective incoming customer data (Cui, Lui, \& Guo, 2012) on social media (Hennig, et al., 2010), but little attention on the business website in the hotel context.

Brand loyalty is important to reduce the cost of production and marketing the product, in turn, increase the profit margins. It occurs when a customer keeps going to purchase a product produced by the same brand instead of a substitute product provided by a competitor. Marketing strategy has been mainly focused on such a sustainable competitive advantage through marketing efforts (Dick \& Basu, 1994).

In the tourism industry, So et al. (2014) said that brand loyalty has not been only strengthened by service consumption experienced but also by CEBs. Moreover, customers are increasingly engaging with the service quality of luxury hotel brand which reflects their values (Rather \& Camilleri, 2019). Besides, Ribbink et al. (2004) indicated that loyalty is attributed to satisfaction and engagement behaviors with the quality of service. For example, customers might be willing to pay more for a booking on the hotel website (Ribbink, Riel, Liljander, \& Streukens, 2004). Nevertheless, loyalty was not the main focus of providers because of the nature of customer' considerable interest and product' diversity and category (Oliver, 1999). The different perspectives on loyalty were based on a different framework for understanding customer loyalty (Uncles, Dowling, \& Hammond, 2003). Guo et al. (2014) emphasized that to gain and regain customer booking intention for loyalty, OTAs competed against hotels by providing online bookers cashback after the stay. Therefore, the consumer-based brand equity has been found at luxury hotels (Liua, Wong, Tseng, Chang, \& Phau, 2017) to boost loyalty, trust and brand evaluations (Harrigan, Evers, Miles, \& Daly, 2017). Thus, it is posited:

H6. Customer perceived CEBs via e-service quality effects brand loyalty 
The study tested the influence of website quality towards satisfaction, CEBs and brand loyalty then measured the mediating role of customer satisfaction between hotel website quality and CEBs. Figure 1 presents our research model and the relationships of constructs.

\section{[Insert Figure 1. The research model and the proposed relationships (owned)]}

\section{Methodology}

A three-section questionnaire was developed to collect data and fulfill the prospect research objectives. Respondents who have experienced in a luxury hotel within Vietnam in 12 months (Law R. H., 2006) to imply the role of understanding the exiting and potential customers' needs (Law \& Leung, 2000). The first four questions were used to identify eligible respondents in the first section, namely,

"Provide the name of any 4-star or 5-star hotels you have stayed in Vietnam the past 12 months?",

"Have you ever experienced on the websites of 4-star or 5-star hotel in Viet Nam?",

"Have you ever booked the room on the websites of 4-star or 5-star hotel in Viet Nam?", and

"Do you intend to book the room on the websites of 4-star or 5-star hotels in the future?"

Both positive and negative answers allowed respondents to go further with the survey.

The four variables included in the second section as described in the path model (e.g. hotel website quality, customer satisfaction, CEBs and brand loyalty). Table 1 shows the constructs with multiple items that followed previous studies closely. We could see that all first-order constructs, including customer cognition of hotel website quality, information and interface, and customer trust reflect the measurement of e-service quality of the hotel and the latent construct such customer satisfaction has been described by indicators (Hair, Sarstedt, Ringle, \& Mena, 2012). The first-order variables affected the second-order variables with formative measurement which are named second-order constructs (perceived hotel website quality and customer satisfaction) (Jarvis, MacKenzie, \& Podsakoff, 2003)

\section{[Insert Table 1. Key references of construct based on reflective indicators]}

Variable attributes were measured in a 7-point Likert scale (from 1=strongly disagree to 7=strongly agree) to expand the number of choice-points which would increase sensitivity without damaging scale reliability (Cummins, 2000) or capture detailed differentiation of agreement levels (Preston \& Colman, 2000). The last section explores characteristics of demographic included gender, age group, time of internet usages, education level, continents, monthly personal income and working experiences, etc. Table 2 depicts the demographics of respondents.

\section{[Inert Table 2. Demographic profile of respondents]}

A group of domestic tourists who are hotel staffs, outbound tour guides, English and tourism lecturers, hotel owners, and freelancers were employed to view the questionnaire for pre-test $(n=12)$. Minor revisions were modified by their comments. Then the pilot test $(n=59)$ was used to make sure that our constructs are consistent. Consequently, the original statements were modified to finalize the questionnaire. The data were collected by using the online approach (links spread on the Facebook account and e-mail invitation) and offline approach within approximately 10 minutes each (face-to-face with domestic and international tourists) with stratified samplings during May - July 2018. The Vietnamese and English questionnaires were in different forms and 
URL links for different respondents. The missing values were removed from these sources, and a total of $321 / 400$ valid responses $(80 \%)$ were retained for further data analysis.

The common method bias or common method variance (CMV) is a normal issue in the quantitative approach when the data were conducted from only one source. Therefore, we tested CMV issue based on Harman's one-factor test (Podsakoff, 2003) to minimize the error terms. The cumulative percentage of total variance was explained $37.08 \%$ and $\mathrm{KMO}$ was 0.805 (chi-square $=6313.800$, $\mathrm{df}=276$, sig. $=0.00$ ). Consequently, the CMV and missing data are not threatened with the dataset of the study.

For this study, Partial Least Squares (PLS) version 2.0 was used to conduct the analysis and test the hypotheses for its well-known tool (Nunkoo, Ramkissoon, \& Gursoy, 2013) for below 200 samples (Hair, Hult, Ringle, \& Sarstedt, 2013) and to gain more inside it (Ringle \& Sarstedt, 2016) in tourism research. Indeed, the levels of loadings and path coefficients have measured through PLS algorithms. Then, testing the hypotheses is continued by PLS bootstrapping with 5000 resamples.

\section{Results \& Discussions}

\subsection{The measurement model}

The composite reliability (CR) and average variance extracted (AVE) were tested for convergent validity of the model, especially $C R$ and AVE values had to exceed the recommended value of 0.7 and 0.5 respectively which can indicate the latent constructs (Hair, Hult, Ringle, \& Sarstedt, 2013). The tables 3 shows the high value of all item loadings from above 0.7 but SQ2 has been excluded as an exception ("Price presentation on website of hotel and OTAs is the same"). So the valid values for $\mathrm{CR}$ and $\mathrm{AVE}$ were retained and pricing quotes are different in the channels of the hotel website and OTAs site

\section{[Insert Table 3. Constructs' reliability and validity]}

The discriminant validity of the study is shown in table 4 . The Fornell-Larcker criterion shows that the square root of each AVE is higher than the related inter-construct correlation in the matrix (except the Brand loyalty variable). This outcome points out the customer's perspective of not being loyal to any brand hotel. It is inclined to study of Uncles et al. (2003) for understanding customer loyalty towards different aspects and frameworks, and observation of Oliver (1999) for customers' concern towards their interest in various products. In addition, the discriminant validity could result better mean by the ratio correlations of heterotrait-monotrait (HTMT) (Henseler, Ringle, \& Sarstedt, 2015). If the value was greater than 0.85 , there would violate the discriminant validity (Kline, 2011). So all the values were accepted, except InforInter (Information and Interface of hotel website) showing that discriminant validity is not a problem of the model; and information and interface of hotel website should be as clear and concise as possible regarding its hotel star rating. The booking process should have simple navigation, response quickly and easily. Table 5 presents the weights of the 1 st-order constructs towards the 2 nd-order construct. The results show that hotel website service quality is a second-order construct with two significant positive 1st-order constructs (service quality perception and trust on the hotel website), but information and interface of hotel websites are a kind of negative first-order constructs. The outcomes indicate that the standard of the hotel will affect the information displayed on the website and it turns to affect the degree of the website interface, such as user-friendly, interaction, design, booking functions, nice and unique images such as unique selling points, etc. Therefore, the customers' perception and belief in the hotel brand name will positively reflect on the hotel website they intend to use. However, they expect that the higher the hotel star rating, the higher the standard. Moreover, the integrity of information and interface must be shown on the website itself. 
The hotel website with a booking engine should be clear, short and concise especially draw readers in with great headlines. The booking process of the hotel website should determine as least steps as possible to make a reservation; all terms and conditions of each rate plan should be straightforward, easily understood and not overly complicated. A study by Sale Cycle found that $13 \%$ of people abandon their travel bookings online because the booking process is too complex.

\section{[Insert Table 4. Discriminant validity]}

\section{[Insert Table 5. The weights of the first and second-order constructs]}

\subsection{The structural model and hypothesis testing}

The structural model and hypotheses were tested through a bootstrapping with 5000 iterations without goodness-of-fit by PLS. Consequently, the structural model of the second-order construct is presented in fig. 2 . The corrected $\mathrm{R} 2$ values of the respective construct explain the explanatory power of the predictor variables. The e-service quality of hotel predicts 59.4 percent of the customer satisfaction. Moreover, customer satisfaction predicts 59.5 percent of CEBs, and both perceived customer satisfaction and CEBs predict 59.4 percent of brand loyalty. Furthermore, customer satisfaction (R2 _ 0.594), CEBs (R2 _ 0.595) and brand loyalty (R2_0.754) can be described as moderate, moderate and substantial, respectively (Chin, Peterson, \& Brown, 2008).

\section{[Insert Figure 2. Structural model of second-order construct]}

Table 6 presents the results of the hypothesis testing. The outcomes show that customer cognition of website service quality (i.e positively trust and customer perception and negatively information and interface) influences customer satisfaction. This in turns affects their CEBs and brand loyalty positively and significantly. The results accept $\mathrm{H} 1, \mathrm{H} 2, \mathrm{H} 4, \mathrm{H} 5$ but $\mathrm{H} 3$ and $\mathrm{H} 6$. This study confirms that website service quality contributes to customer satisfaction, then influences their CEBs and brand loyalty. The outcomes are not inclined to a study of Ha (1998) and So et al (2014) for the positive relationships of brand loyalty focus on the CEBs or customer satisfaction through service consumption (Ribbink, Riel, Liljander, \& Streukens, 2004). In addition, the service quality of the hotel website is exerting pressure on customer cognition. It implies that an excellent website service quality can prove to be excited and eager to earn higher customer satisfaction and CEBs level. For instance, customers who likely engage with hotel websites, are spent good time with excellent service quality of hotel websites. It is therefore imperative for practitioners to provide proper website service quality via integrity information with friendly users, trustworthy site and positive customer perception of the hotel website to go beyond customer expectations. Because customers may judge a hotel service quality of its representative website, such as a killer landing page with attractive images and strong headlines which connect with guest' emotion can be benefit-driven. When the hotels can determine booking conditions, behavior, and lifestyle of customers, which will lead to a better understanding of what choices customers are willing to make. And if the hotel knows the customer's value proposition, better pricing and decisions on restrictions can be made.

\section{[Insert Table 6. Testing of hypotheses]}

\subsection{The mediation effect of customer satisfaction}

The role of e-commerce service on hotel website has not been cared much, especially when it comes to as an exogenous construct to earn customer satisfaction and CEBs possible as endogenous constructs in this model. Therefore, we observed the effect of customer satisfaction as a mediator restricted directly by service quality of the hotel website and CEBs. The conditions to exist mediation effect in the study were obtained (Baron \& Kenny, 1986). The three conditions 
as b12, b13, and b23 were significantly accepted to take advantage of e-service quality into customers' experiences (Zeng, 2012) and satisfaction (Bai B. L., 2008). The last condition can be full mediation if the parameter value of service quality and CEBs is insignificant than the parameter estimate of bwq to bCEBs. However, the study results in partial mediation, due to less significance of parameter estimate of service quality and CEBs than bwq to bCEBs. Accordingly, the customer satisfaction had a partial mediating role $(\mathrm{b} 13=.0034, \mathrm{t}=15.17051$, and bwq to $\mathrm{bCEBs}=.00480, \mathrm{t}=2.3311)$. The indirect effect of customer satisfaction here explained its relationship between CEBs and the tourism service (Cheung, Lee, \& Jin, 2011) for visual approach (Cheng, 2015) we cannot afford to ignore (Cabiddu F. C., 2014). The indirect effect of hotel website quality on CEBs through customer satisfaction was .00015 , which came from b12*b23. The total effect hotel web-site quality on CEBs through customer satisfaction was 0.0482 , which collected from $\mathrm{b} 13+\mathrm{b} 12 * \mathrm{~b} 23$ with $\mathrm{p}<.05$. The outputs, enhanced engagement of buyers and sellers, especially on the internet (Hennig, et al., 2010) to obtain incoming customer data (Cui, Lui, \& Guo, 2012) for further marketing business.

\section{Conclusions \& Implications.}

The hotel websites should be offering various benefits for users and suppliers and increasing as an important booking and distribution channel (Hsu, Chang, \& Chen, 2012) to foster relationship management which builds up customer satisfaction, customer behaviours (Rather R. A., 2017)(Ponte, Carvajal, \& Rodriguez, 2015) (Rather, Hollebeek, \& Islam, 2019) but brand loyalty (Ribbink, Riel, Liljander, \& Streukens, 2004) (So K., King, Sparks, \& Wang, 2014). Hotel website can be used conveniently by lookers for information and transactions (Amaro \& Duarte, 2015). There are arguments to explore the feature, content and side effects of website service, but lack of research from the customer perspective of website quality and how it influences the customer satisfaction, CEBs and brand loyalty towards luxury hotels.

From a theoretical perspective, the study aims to fill the research gaps and confirms the correlation between customer cognition of hotel website service quality and customer satisfaction as predictors of CEBs on the website of 4 and 5-star hotels. In the century that e-commerce is more prevalent, attributes of e-service quality are a vital role in online travel shopping. Internet users are favorable engaged in travel shopping (Bai, Law, \& Wen, 2008) and searching it compatible with their lifestyle and benefits (Anderson, Fornell, \& Lehman, 1994). CEB used in this current study as one of the research limitations of Doorn et al. (2001) and Hollebeek et al. (2010) on the measurements of customer engagement with the hotel website. Besides, the study encourages other scholars to adopt verified measurements items for CEB in future studies.

Furthermore, it should be aware of that online shopping is a common practice, regarding consumer trust on hotel website would risk to affect satisfaction and intention to purchase travel online in practical (Belanche, 2012). These findings are inclined and provided more pieces of evidence about booking on the website of the hotel to the study of Bai et al. (2008), and Wang et al. (2015) where system service quality and information quality have measured the significance of customers' perceptions and behaviors. However, this study added the role of trust in the e-service quality components, in turns impacts positively the degree of customer satisfaction, CEBs and brand loyalty.

In addition, as the mediating role, the higher levels of satisfaction, the higher positive engagements of customers towards e-service quality. On the contrary, the more understanding the customer' interest, demand, emotion and behaviors of the targeted customers towards the hotel website' creativity, content and booking process, the more successful in building customer' content and 
leading to repeated guests somehow. Therefore, hotel managers need to ensure better website performance. It can attract more customers to intend to purchase. Moreover, its benefit is driven for higher yield and competitive positioning in the current and potential markets.

Moreover, the website' information and interface prove to be a must-have functionality of hotel website service quality. In e-commerce, it is a core value where customers can not know or inspect the items before buying but rely on-site' information. It is therefore imperative for hotel managers to provide more resources; keep up-to-date information; and build trust and accuracy of websites for customers' involvement.

Although the study has provided shed light on important issues into the e-service of the tourism industry, limitations need to be considered for further research. There are only three dimensions of website quality hotel website (information and interface, customer cognition of hotel website and customer trust on hotel website). Nevertheless, there are more important factors related to website service quality (i.e. booking intention, room rate strategy, perceived flow, perceived enjoyment, security and privacy, travel purposes, cultural factors, etc.). Also, limitations are inclined with timing, budget, data availability and accessibility and other practical concerns.

Acknowledgement: The research for this paper was financially supported by the Internal Grant Agency of Faculty of Management and Economics, Tomas Bata University in Zlin, Grant no.IGA/FaME/2018/009

\section{References}

Abdullah, D., Jayaraman, K., \& Kamal, S. B. (2016). A Conceptual Model of Interactive Hotel Website: The Role of Perceived Website Interactivity and Customer Perceived Value Toward Website Revisit Intention. Procedia Economics and Finance, 37, 170-175. doi:10.1016/S2212-5671(16)30109-5

Ahmad, W., \& Sun, J. (2018). Modeling consumer distrust of online hotel reviews. International Journal of Hospitality Management, 71, 77-90. doi:10.1016/j.ijhm.2017.12.005

Ahn, J., \& Back, K. J. (2018). Antecedents and consequences of customer brand engagement in integrated resorts. International Journal of Hospitality Management, 75, 144-152.

Ajzen, I. (1991). The theory of planned behavior. Organizational Behavior and Human Decision Processes, 50, 179211. doi:https://doi.org/10.1016/0749-5978(91)90020-T

Aladwani, A., \& Palvia, P. (2002). Developing and validating an instrument for measuring user-perceived web quality. Information \& Management, 39, 467-476.

Albert A. Barreda, A. B. (2016). Online branding: Development of hotel branding through interactivity theory. Tourism Management, 57, 180-192. doi:10.1016/j.tourman.2016.06.007

Ali, F., \& Kim, W. (2015). A comparative study of CB-SEM and PLS-SEM for theory development in hospitality research. 3rd World Research Summit for Tourism and Hospitality. Orlando, FL.

Amaro, S., \& Duarte, P. (2015). An integrative model of consumers' intentions to purchase travel online. Tourism Management, 46, 64-79. doi:https://doi.org/10.1016/j.tourman.2014.06.006

Anderson, C. (2009). The billboard effect: Online travel agent impact on non-OTA reservation volume . Electronic article, Cornell Hospitality Report. doi:https://scholarship.sha.cornell.edu/chrpubs/2/

Anderson, E., Fornell, C., \& Lehman, D. (1994). Customer satisfaction, market share, and profitability: Findings from Sweden. Journal of Marketing, 58(3), 53-56. doi:DOI: 10.2307/1252310

Anderson, J., \& Gerbing, D. (1988). Structural modeling in practice: a review and recommended two-step approach. Psychological Bulletin, 103(3), 411-423.

Anonymous. (2017, 06 01). Vietnamnet . Retrieved from Over 345 million in FDI poured into property: http://english.vietnamnet.vn/fms/business/173737/over--345-million-in-fdi-poured-into-propertysector.html. 
Anonymous. (2017, 6). Vietnamnews. Retrieved 12 2018, from Vietnamnews: http://vietnamnews.vn/lifestyle/379600/viet-nam-seeks-way-to-boost-online-travel-market.html\#sUFM0jAwsaQ5GIck.99

Anonymous. (2018). Hospitailty sector - EVBN The Hospitality market in Vietnam. Vietnam: EU-Vietnam business network. $\quad$ Retrieved 2018, from file:///E:/hoc\%20PhD/hoc\%20PhD/publication/zlin\%20_2018/vietnam\%20report/EVBN_HospitalityFinal_Report-Update-180517.pdf

Anonymous. (2018). statista. Retrieved 12 2018, from https://www.statista.com/outlook/262/100/online-travelbooking/worldwide

$\begin{array}{llllll}\text { Anonymous. } & \text { (2018). } & \text { Statista. } & \text { Retrieved } & 12 & \text { 2018, }\end{array}$ https://www.statista.com/outlook/267/100/hotels/worldwide

Anonymous. (2018). Statista. Retrieved 9 2018, from https://www.statista.com/outlook/262/127/online-travelbooking/vietnam

Anonymous. (2018). Statistica. Retrieved from https://www.statista.com/outlook/262/127/online-travelbooking/vietnam

Ariff, M., Yan, N., Zakuan, N., Rahim, K., \& Ismail, K. (2014). Online purchasing behavior of Malaysia's young consumers. In S. K. Ford Lumban Gaol (Ed.), Recent Trends in Social and Behaviour Sciences (p. 8). Group, Taylor \& Francis.

Aurelio Mauri, R. M. (2013). Web reviews influence on expectations and purchasing intentions of hotel potential customers. International Journal of Hospitality Management, 34, 99-107. doi:10.1016/j.ijhm.2013.02.012

Bai, B., Law, R., \& Wen, I. (2008). The impact of website quality on customer satisfaction and purchase intentions: Evidence from Chinese online visitors. International Journal of Hospitality Management, 27, 391-402. doi:doi:10.1016/j.ijhm.2007.10.008

Baron, R., \& Kenny, D. (1986). The moderator-mediator variable distinction insocial psychological research: conceptual, strategic, and statistical considerations. J. Pers. Soc. Psychol, 51(6), 1173-1182.

Bauer, H. H., Hammerschmidt, M., \& Falk, T. (2005). Measuring the quality of e-banking portals. International Journal of Bank Marketing , 23, 153-175. doi:10.1108/02652320510584395

Belanche, D. C. (2012). Website quality, consumer satisfaction and the intention to use a website: the moderating effect ofperceived risk. J. Retailing Consum. Serv., 19(1), 24-132.

Ben, A. A. (2017). Website interactivity and brand development of online travel agencies in China: The moderating role of age. Journal of Business Research. doi:10.1016/j.jbusres.2017.09.046

Bevanda, V., Grzinic, J., \& Cervar, E. (2008). Analysing The Users` Perception Of Web Design Quality By Data Mining tool. Tourism and Hospitality Management, 14(2), 251-262.

Bilgihan, A., \& Bujisic, M. (2014). The effect of website features in online relationship marketing: A case of online hotel booking. Electronic Commerce Research and Applications, 14(4), 222-232.

Bowden, J. L.-H. (2014). The Process of Customer Engagement: A Conceptual Framework. Journal of Marketing Theory and Practice,, 14(1), 63-74. doi:https://doi.org/10.2753/MTP1069-6679170105

Bowen, J. T., \& Chen, S.L. (2001). The relationship between customer loyalty and customer satisfaction. International Journal of Contemporary Hospitality Management, 13(5), 213 - 217. doi:https://doi.org/10.1108/09596110110395893

Brodie, R. J., Hollebeek, L. D., Juric, B., \& Ilic, A. (2011). Customer Engagement: Conceptual Domain, Fundamental Propositions, and Implications for Research. Journal of Service Research, 14(3), 252-271. doi:https://doi.org/10.1177/1094670511411703

Buhalis, D. (1998). Strategic use of information technologies in the tourism industry. Tourism Management, 19(5), 409-421. doi:https://doi.org/10.1016/S0261-5177(98)00038-7

Buhalis, D. (2003). eTourism: Information technology for strategic tourism management. London: Prentice Hall.

Cabiddu, F., Carlo, M. D., \& Piccoli, G. (2014). Social media affordances: Enabling customer engagement. Annals of Tourism Research , 48, 175-192. doi:https://doi.org/10.1016/j.annals.2014.06.003

Casaló, L., Flavián, C., \& Guinalíu, M. (2008). The role of perceived usability, reputation, satisfaction and consumer familiarity on the website loyalty formation process. Computers in Human Behavior, 24(2), 325-345.

Chang, H., \& Chen, S. (2008). The impact of online store environment cues on purchase intention: Trust and perceived risk as a mediator. Online Information Review, 32(6), 818-841. doi:DOI $10.1108 / 14684520810923953$ 
Chathoth, P. K. (2007). The impact of information technology on hotel operations, service management and transaction costs: A conceptual framework for full-service hotel firms. International Journal of Hospitality Management, 26, 395-408. doi:10.1016/j.ijhm.2006.03.004

Chathoth, P. K., Ungson, G. R., Altinay, L., S.W.Chan, E., Harrington, R., \& Okumus, F. (2014). Barriers affecting organisational adoption of higher order customer engagement in tourism service interactions. Tourism Management, 42, 181-193. doi:https://doi.org/10.1016/j.tourman.2013.12.002

Chen, C. (2006). Identifying significant factors influencing consumer trust in an Online Travel Site. Information Technology \& Tourism, 8(3), 197-214.

Chen, S. C., \& Dhillon, G. S. (2003). Interpreting Dimensions of Consumer Trust in E-Commerce. Information Technology and Management, 4(2), 303-318.

Cheng, M. E. (2015). Social media in tourism: A visual analytic approach. . Current Issues in Tourism, 18, 1080-1087.

Chetty, P., \& Datt, S. $(2015,2$ 6). One way ANOVA test in SPSS. Retrieved from projectguru: https://www.projectguru.in/publications/one-way-anova-test-spss/

Cheung, C. M., Lee, M. K., \& Jin, X.-L. (2011). Customer engagement in an online platform: A conceptual model and scale development. The proceedings of the thirty-second international conference on information systems (ICIS), . Shanghai, China.

Chin, W., Peterson, R., \& Brown, P. (2008). Structural equation modelling in marketing: some practical reminders. Journal of Marketing Theory and Practice, 16(4), 287-298.

Chiou, W., Lin, C., \& Perng, C. (2011). A strategic website evaluation of online travel agencies. Tourism Management, 32, 1463-1473. doi:10.1016/j.tourman.2010.12.007

Chunyu Li, G. C. (2017). The signaling effect of management response in engaging customers: A study of the hotel industry. Tourism Management, 62, 42-53. doi:10.1016/j.tourman.2017.03.009

Clampet, J. (2016, 4 25). Everything You Wanted to Know About the Hotel Industry's Gripes Against OTAs. Retrieved 6 25, 2018, from skift: https://skift.com/2016/04/25/everything-you-ever-wanted-to-know-about-hotelindustrys-complaints-against-otas/

Collins, G. C. (2013). Hospitality Information Technology: Learning How to Use It.

Corritore, C. L., Kracher, B., \& Wiedenbeck, S. (2003). On-line trust: concepts, evolving themes, a model. International Journal of Human-Computer Studies, 58(6), 737-758.

Cui, G., Lui, H.-K., \& Guo, X. (2012). The effect of online consumer reviews on new product sales. International Journal of Electronic Commerce, 17(1), 39-57.

Cummins, R. G. (2000). Why we should not use 5-point Likert scales: The case for subjective quality of life measurement. Retrieved from University: https://www.deakin.edu.au/research/acqol/iwbg/correspondence/2002/Cummins_Gullone_2000_Likert_ Scales.doc

Dandison, H. K. (2016). Consumers' acceptance of information and communications technology in tourism: Telematics and Informatics. doi:http://dx.doi.org/10.1016/j.tele.

Das, T., \& Teng, B. (1998). Between trust and control: developing confidence inpartner cooperation in alliances. . Academy of Management, 23(3), 491-512.

Davidow, H., \& Uttal, B. (1989). Service Companies: Focus or Falter. Harvard Business Review, 77-85.

Davis, F. D. (1989). Perceived usefulness, perceived ease of use, and user acceptance of information technology. Management Science, 35(8), 982-1003.

Díaz, E., \& Koutra, C. (2013). Evaluation of the Persuasive Features of Hotel Chains Websites: A Latent Class Segmentation Analysis. International Journal of Hospitality Management.

Dick, A., \& Basu, K. (1994). Customer loyalty: toward an integrated conceptual framework. Journal of Academy of Marketing Science, 22(2), 99-113.

Dolatabadi, H. R., \& Pool, J. K. (2013). Analysis electronic service quality through E-S-qualscale: The case study of Nowshahr hotel. Research Journal of Applied Sciences, Engineering and Technology, 5(7), 2321-2326.

Doorn, J. V., Lemon, K. N., Mittal, V., Nass, S., Pick, D., Pirner, P., \& Verhoef, P. C. (2010). Customer Engagement Behavior: Theoretical Foundations and Research Directions. Journal of Service Research, 13(3), 253-266. doi:https://doi.org/10.1177/1094670510375599

Everard, A., \& Galletta, D. F. (2014). How Presentation Flaws Affect Perceived Site Quality, Trust, and Intention to Purchase from an Online Store. Journal of Management Information Systems, 22, 56-95. doi:10.2753/MIS0742-1222220303 
Ferguson, J. L. (2014). Implementing price increases in turbulent economies: Pricing approaches for reducing perceptions of price unfairness. Journal of Business Research, 67, 2732-2737. doi:10.1016/j.jbusres.2013.03.023

Fishbein, M., \& Ajzen, I. (1970). The prediction of behavior from attitudinal and normative variables. Journal of Experimental Social Psychology, 6(4), 466-487. doi:https://doi.org/10.1016/0022-1031(70)90057-0

Françoise, V. T. (2018). Does brand-consumer social sharing matter? A relational framework of customer engagement to brand-hosted social media. Journal of Business Research, 85, 175-184. doi:10.1016/j.jbusres.2017.12.050

Fuentes, E. M. (2016). Are guests of the same opinion as the hotel star-rate classification system? Journal of Hospitality and Tourism Management, 29, 126-134. doi:10.1016/j.jhtm.2016.06.006

Gavilan, D., Avello, M., \& Navarro, G. M. (2018). The influence of online ratings and reviews on hotel booking. Tourism Management, 66, 53e61. doi:10.1016/j.tourman.2017.10.018

Guo, X., Zheng, X., Ling, L., \& Yang, C. (2014). Online coopetition between hotels and online travel agencies: From the perspective of cash back after stay. Tourism Management Perspectives, 12, 104-112. doi:10.1016/j.tmp.2014.09.005

Ha, C. L. (1998). The theory of reasoned action applied to brand loyalty. Journal of Product \& Brand Management, 7(1), 51-61. doi:https://doi.org/10.1108/10610429810209737

Hair Jr, J. F. (2014). Partialleast squares structural equation modeling (PLS-SEM): An emerging tool in business research. European Business Review, 26(2), $106-121$.

Hair, J. F. (2011). PLS-SEM: Indeed a Silver Bullet. The Journal of Marketing Theory and Practice, 19(2), 139-152. doi:10.2753/MTP1069-6679190202

Hair, J. F., Sarstedt, M., Ringle, C. M., \& Mena, J. A. (2012). An assessment of the use of partial least squares structural equation modeling in marketing research. Journal of the Academy of Marketing Science, 40(3), 414-433.

Hair, J., Hult, G., Ringle, C., \& Sarstedt, M. (2013). A Primer on Partial Least Squares Structural Equation Modelling (PLS-SEM). London.: Sage Publications.

Harrigan, P., Evers, U., Miles, M., \& Daly, T. (2017). Customer engagement with tourism social media brands. Tourism Management, 59, 597-609. doi:https://doi.org/10.1016/j.tourman.2016.09.015

Hasanov, J. K. (2015). The impact of website quality on online purchaseintention of organic food in Malaysia: a WebQual Model approach. Proc.Comput. Sci., 72, 382-389.

Hennig, T., Malthouse, E. C., Friege, C., Gensler, S., Lobschat, L., \& Rangaswamy, A. (2010). The impact of new media on customer relationships. Journal of Service Research, 13(3), 311-330.

Henseler, J., Ringle, C., \& Sarstedt, M. (2015). A new criterion for assessing discriminantvalidity in variance-based structural equation modeling. Journal of the Academy of Marketing Science, 43(1), 115-135.

Ho, C., \& Lee, Y. (2007). The development of an e-travel service quality scale. Tourism Management, 28(6), 14341449. doi:https://doi.org/10.1016/j.tourman.2006.12.002

Hollebeek, L. D. (2010). Demystifying customer brand engagement: Exploring the loyalty nexus. Journal of Marketing Management, 27(7), 785-807. doi:https://doi.org/10.1080/0267257X.2010.500132

Howe, N. (2017, 7 31). Hotels Versus OTAs: Who Is Winning Over Millennial Travelers. Retrieved from forbes: https://www.forbes.com/sites/neilhowe/2017/07/31/hotels-versus-otas-who-is-winning-over-millennialtravelers/\#191a9bc9277a

Hsieh, Y. (2012). Hotel companies' environmental policies and practices: a contentanalysis of their web pages. Int. J. Contemp. Hospitality Manage, 24, 97-121.

Hsu, C.L., Chang, K.C., \& Chen, M.C. (2012). The impact of website quality on customer satisfaction and purchase intention: perceived playfulness and perceived flow as mediators. Information Systems and e-Business Management, 10(4), 549-570. doi:https://doi.org/10.1007/s10257-011-0181-5

Hsu, R., \& Cathy, H. (2005). Customers' perceptions on the importance of hotel web site dimensions and attributes. (E. G. Limited, Ed.) International Journal of Contemporary Hospitality Management, 17, 493-503. doi:DOI 10.1108/09596110510612130

Hung, C.L. (2017). Online positioning through website service quality: A case of star-rated hotels in Taiwan. Journal of Hospitality and Tourism Management, 31, 181-188. doi:10.1016/j.jhtm.2016.12.004

Ip, C., Law, R., \& Lee, H. (2012). The Evaluation of Hotel Website Functionality by Fuzzy Analytic Hierarchy Process. Journal of Travel \& Tourism Marketing, 29, 263-278. doi:10.1080/10548408.2012.666173

Irene, L. W. (2017). The effect of online reviews on hotel booking intention: The role of. International Journal of Hospitality Management, 66, 54-65. doi:10.1016/j.ijhm.2017.06.007 
Islam, J. U., Hollebeek, L. D., Rahman, Z., Khan, I., \& Rasool, A. (2019). Customer engagement in the service context: An empirical investigation of the construct, its antecedents and consequences. Journal of Retailing and Consumer Services, 50, 277-285.

Jarvis, C. B., MacKenzie, S. B., \& Podsakoff, P. M. (2003). A critical review of construct indicators and measurement model misspecification in marketing and consumer research. Journal of Consumer Research, 30(2), 199-218.

Jeong, M., Oh, H., \& Gregoire, M. (2003). Conceptualizing Web site quality and its consequences in the lodging industry. Hospitality Management, 22, 161-175. doi:10.1016/S0278-4319(03)00016-1

Jiang, Z., Wang, W., Tan, B. C., \& Yu, J. (2016). The determinants and impacts of aesthetics in users' first interaction with websites. J. Manage. Inf. Syst, 33(1), 229-259.

Kamarulzaman, Y. (2007). Adoption of travel e-shopping in the UK. International Journal of Retail \& Distribution Management, 35(9), 703-719.

Kim, M. J. (2011). The effect of perceived trust on electronic commerce: Shopping online for tourism products and services in South Korea. Tourism Management, 32, 256-265. doi:https://doi.org/10.1016/j.tourman.2010.01.011

Kim, M. J., Chung, N., \& Lee, C. K. (2011). The effect of perceived trust on electronic commerce: Shopping online for tourism products and services in South Korea. Tourism Management, 32, 256-265. doi:https://doi.org/10.1016/j.tourman.2010.01.011

Kotler, P. (1984). Marketing Management: Analysis, Planning, and Control (5 ed.). Prentice Hall.

Kumar, N. S. (1995). The effects of perceivedinterdependence on dealer attitudes? J. Mark. Res., 32(3), 348-356.

Kumar, V., Rajan, B., Gupta, S., \& Pozza, I. D. (2019). Customer engagement in service. Journal of the Academy of Marketing Science, 47(1), 138-160.

Ladhari, R., \& Michaud, M. (2015). eWOM effects on hotel booking intentions, attitudes, trust, and website perceptions. International Journal of Hospitality Management, 46, 36-45. doi:10.1016/j.ijhm.2015.01.010

Law, R. H. (2006). Importance of Hotel Website Dimensions and Attributes: Perceptions of Online Browsers and Online Purchasers. Journal of Hospitality \& Tourism Research, 30(3), 295-312.

Law, R. Q. (2010). Progress in tourism management: A review of website evaluation in tourism research. . Tourism Management, 31(3), 97-313. doi:doi:10.1016/j.tourman.2009.11.007

Law, R., \& Leung, R. (2000). A Study of Airlines' Online Reservation Services on the Internet. Journal of Travel Research, 39, 202-211. doi:https://doi.org/10.1177/004728750003900210

Lee, C. H. (2014). Toward understanding consumer processing of negative online word-of-mouth communication: The roles of opinion consensus and organizational response strategies. Journal of Hospitality \&Tourism Research, 38, 330-360.

Lee, J., \& Morrison, A. M. (2010). A comparative study of web site. Journal of Hospitality and Tourism Technology, 1, 50-67. doi:DOI 10.1108/17579881011023016

Lee, Y. L. (2010). An empirical investigation of electronic word-of-mouth: Informational motive and corporate response strategy. Computers in Human Behavior, 26, 1073-1080.

Leung, D., Law, R., \& Lee, H. “. (2016). A Modified Model for Hotel Website Functionality Evaluation. Journal of Travel \& Tourism Marketing, 33, 1268-1285.

Li, H., Ye, Q., \& Law, R. (2013). Determinants of Customer Satisfaction in the Hotel Industry: An Application of Online Review Analysis. Asia Pacific Journal of Tourism Research, 18, 784-802. doi:10.1080/10941665.2012.708351

Li, L., Peng, M., Jiang, N., \& Law, R. (2017). An empirical study on the influence of economy hotel website quality on online booking intentions. International Journal of Hospitality Management, 63, 1-10.

Lien, C.H., Wen, M.J., Huang, L.C., \& Wu, K.L. (2015). Online hotel booking: The effects of brand image, price, trust and value on purchase intentions. Asia Pacific Management Review, 1-9. doi:10.1016/j.apmrv.2015.03.005

Linda D. Hollebeek, M. S. (2014). Consumer Brand Engagement in Social Media: Conceptualization, Scale Development and Validation. Journal of Interactive Marketing , 28, 149-165. doi:10.1016/j.intmar.2013.12.002

Ling, L., Dong, Y., Guo, X., \& Liang, L. (2015). Availability management of hotel rooms under cooperation with online travel agencies. International Journal of Hospitality Management, 50, 145-152. doi:https://doi.org/10.1016/j.ijhm.2015.07.005

Liua, M. K. (2018). Trust transfer in social media brand communities: The role of consumer engagement. International Journal of Information Management, 41, 1-13. doi:10.1016/j.ijinfomgt.2018.02.006

Liu, et al. (2013). Analyzing changes in hotel customers' expectations by trip mode. International Journal of Hospitality Management, 34, 359-371. 
Liu, C., Arnett, K. P., \& Litecky, C. (2000). Design Quality of Websites for Electronic Commerce: Fortune 1000 Webmasters' Evaluations. 10(2), 120-129.

Liu, J. N., \& Zhang, E. Y. (2014). An investigation of factors affecting customer selection of online hotel. International Journal of Hospitality Management, 39, 71-83. doi:10.1016/j.ijhm.2014.01.011

Liu, S., Law, R., Rong, J., Li, G., \& Hall, J. (2013). Analyzing changes in hotel customers' expectations by trip mode. International Journal of Hospitality Management, 34, 359-371. doi:https://doi.org/10.1016/j.ijhm.2012.11.011

Liua, M. T., Wong, I. A., Tseng, T.-H., Chang, A. W.-Y., \& Phau, I. (2017). Applying consumer-based brand equity in luxury hotel branding. Journal of Business Research . doi:10.1016/j.jbusres.2017.06.014

Ling, X. G. (2014). Opening the online marketplace: An examination of hotel pricing and travel agency on-line distribution of rooms. Tourism Management, 45, 234-243. doi:10.1016/j.tourman.2014.05.003

Loiacono, E. T., Watson, R. T., \& Goodhue, D. L. (2002). Webqual: a measure of website quality. AMA Winter Conference. . Austin, TX.

Luis V. Casalóa, C. F. (2015). Do online hotel rating schemes influence booking behaviors? International Journal of Hospitality Management, 49, 28-36.

Ma, A., Law, R., \& Ye, Q. (2008). The functionality of the performance of international chain hotel websites in Hong Kong, Shanghai and Beijing. Asian journal of tourism and hospitality research, 2, 13-24. Retrieved from http://hdl.handle.net/10397/63802

Martín, H. S., \& Herrero, Á. (2012). Influence of the user's psychological factors on the online purchase intention in rural tourism: Integrating innovativeness to the UTAUT framework. Tourism Management, 33(2), 341-350. doi:https://doi.org/10.1016/j.tourman.2011.04.003

Matthew, I. A. (2017). Applying consumer-based brand equity in luxury hotel branding. Journal of Business Research. doi:10.1016/j.jbusres.2017.06.014

McDonald, N. (2018). we are social. Retrieved 12 2018, from https://wearesocial.com/us/blog/2018/01/globaldigital-report-2018

McKnight, D. H., Choudhury, V., \& Kacmar, C. (2002). Developing and validating trust measures for e-commerce: an integrative typology. Information Systems Research, 13(3), 334-359.

McMullan, R., \& Gilmore, A. (2008). Customer loyalty: an empirical study. European Journal of Marketing, 42, 10841094. doi:https://doi.org/10.1108/03090560810891154

Mollen, A., \& Wilson, H. (2010). Engagement, telepresence and interactivity in online consumer experience: Reconciling scholastic and managerial perspectives. Journal of Business Research, 63(9), 919-925. doi:https://doi.org/10.1016/j.jbusres.2009.05.014

Morgan, R., \& Hunt, S. (1994). The commitment-trust theory of relationship marketing. Journal of Marketing, 58(3), 20-38.

Mukherjee, A., \& Nath, P. (2007). Role of electronic trust in online retailing: A re-examination of the commitment-trust theory. European Journal of Marketing, 41, 1173-1202. doi:10.1108/03090560710773390

Musante, M. D., Bojanic, D. C., \& Zhang, J. J. (2009). An evaluation of hotel website attribute utilization and effectiveness by hotel class. Journal of Vacation Marketing, 15(3), 203-215.

Nath, A., \& Singh, R. (2010). Evaluating the Performance and Quality of Web Services in Electronic Marketplaces. The 15th Americas Conference on Information Systems, AMCIS 2009, 7, pp. 43-59. San Francisco, California, USA.

Noone, B. M., \& Mattila, A. S. (2009). Hotel revenue management and the Internet: The effect of price presentation strategies on customers' willingness to book. International Journal of Hospitality Management, 28, 272279.

Nunkoo, R., Ramkissoon, H., \& Gursoy, D. (2013). Use of Structural Equation Modeling in Tourism Research: Past, Present, and Future. Journal of Travel Research, 1-13.

Oliver, R. L. (1999). Whence customer loyalty? Journal of Marketing, 63(4), 33-44. doi:https://doi.org/10.1177/00222429990634s105

Patrick, P. D., Sophie, T. v., \& Christian , H. (2018). Digital marketing strategies, online reviews and hotel performance. International Journal of Hospitality Management, 17, 47-55. doi:10.1016/j.ijhm.2018.01.003

Pei, Y.H. (2018). Assessing the helpfulness of online hotel reviews: A classification-based approach. Telematics and Informatics. doi:10.1016/j.tele.2018.01.001

Podsakoff, P. M. (2003). Common method biases in behavioral research: a critical review of the literature and recommended remedies. Journal of Applied Psychology, 88, 879-903. 
Ponte, E., Carvajal, E., \& Rodriguez, E. (2015). Influence of trust and perceived value on the intention to purchase travel online: integrating the effects of assurance on trust antecedents. Tourism Management, 47, 286-302. doi:https://doi.org/10.1016/j.tourman.2014.10.009

Pranic'ı, L. P. (2014). Hotel website performance evidencefrom a transition country. Tourism Hospitality Managent, $20,45-60$.

Preston, C., \& Colman, A. (2000). Optimal number of response categories in ratingscales: reliability, validity, discriminating power, and respondent preferences. Acta Psychologica, 14(1), 1-15.

Priya, C., \& Sharma, P. (2015, 1 9). Linear regression analysis using SPSS. Retrieved from projectguru: https://www.projectguru.in/publications/17-linear-regression-analysis/

Rahimnia, F. H. (2013). The impact of website content dimensionand eTrust on e-marketing effectiveness: the case of Iranian commercialsaffron corporations. Inf. Manage, 50, 240-247.

Rasoolimanesh, S. M., Md Noor, S., Schuberth, F., \& Jaafar, M. (2019). Investigating the effects of tourist engagement on satisfaction and loyalty. The Service Industries Journal, 1-16.

Rather, A. R. (2018). Exploring customers' attitudes towards the hospitality brands in India: A social identity perspective. In The branding of tourist destinations: Theoretical and empirical insights . Emerald Publishing Limited., 207-231.

Rather, R. A. (2017). Customer engagement for evaluating customer relationships in hotel industry. European Journal of Tourism, Hospitality and Recreation, 8(1), 1-13.

Rather, R. A. (2018). Investigating the impact of customer brand identification on hospitality brand loyalty: A social identity perspective. Journal of Hospitality Marketing \& Management, 27(5), 487-513.

Rather, R. A. (2019). Consequences of consumer engagement in service marketing: An empirical exploration. Journal of Global Marketing, , 1-20.

Rather, R. A., \& Camilleri, M. A. (2019). The effects of service quality and consumer-brand value congruity on hospitality brand loyalty. An International Journal of Tourism and Hospitality Research. doi:DOI: 10.1080/13032917.2019.1650289

Rather, R. A., \& Hollebeek, L. D. (2019). Exploring and validating social identification and social exchange-based drivers of hospitality customer loyalty. International Journal of Contemporary Hospitality Management. .

Rather, R. A., \& Sharma, J. (2017). Customer engagement for evaluating customer relationships in hotel industry. European Journal of Tourism, Hospitality and Recreation, 8(1), 1-13.

Rather, R. A., Hollebeek, L. D., \& Islam, J. U. (2019). Tourism-based customer engagement: the construct, antecedents, and consequences. The Service Industries Journal, 1-22.

Rather, R. A., Tehseen, S., \& Parrey, S. H. (2018). Promoting customer brand engagement and brand loyalty through customer brand identification and value congruity. Spanish Journal of Marketing-ESIC, 22(3), 319-337.

Rather, R. A., Tehseen, S., Itoo, M. H., \& Parrey, S. H. (2019). Customer brand identification, affective commitment, customer satisfaction, and brand trust as antecedents of customer behavioral intention of loyalty: An empirical study in the hospitality. Journal of Global Scholars of Marketing Science, 29(2), 196-217.

Rianthong, N., Dumrongsiri, A., \& Kohda, Y. (2016). Optimizing customer searching experience of online hotel booking by sequencing hotel choices and selecting online reviews: A mathematical model approach. Tourism Management Perspectives, 20, 55-65. doi:10.1016/j.tmp.2016.07.003

Ribbink, D., Riel, A. C., Liljander, V., \& Streukens, S. (2004). Comfort your online customer: quality, trust and loyalty on the internet. Managing Service Quality: An International Journal, 14(6), 446-456. doi:https://doi.org/10.1108/09604520410569784

Ringle, C., \& Sarstedt, M. (2016). Gain more insight from your PLS-SEM results: The importance-performance map analysis. Industrial Management \& Data Systems, 116(9), 1865-1886.

Roy, S. K. (2018). Customer engagement behavior in individualistic and collectivistic markets. Journal of Business Research, 86, 281-290.

Roy, S. K., Balaji, M. S., Soutar, G., Lassar, W. M., \& Roy, R. (2018). Customer engagement behavior in individualistic and collectivistic markets. Journal of Business Research, 86, 281-290.

Salavati, S., \& Hashim, N. (2015). Website adoption and performance by Iranian hotels. Tourism Management, 46, 367-374.

Schmidt, S., Cantallops, A. S., \& Santos, C. P. (2008). The characteristics of hotel websites and their implications for website effectiveness. International Journal of Hospitality Management, 27, 504-516. doi:10.1016/j.ijhm.2007.08.002 
So, K. K., King, C., \& Sparks, B. (2012). Customer Engagement With Tourism Brands: Scale Development and Validation. Journal of Hospitality \& Tourism Research. doi:https://doi.org/10.1177/1096348012451456

So, K., King, C., Sparks, B., \& Wang, Y. (2014). The Role of Customer Engagement in Building Consumer Loyalty to Tourism Brands. Journal of Travel Research, 1-15. doi:https://doi.org/10.1177/0047287514541008

Soyoung Boo, J. A. (2018). Meeting planners' online reviews of destination hotels: A twofold content analysis approach. Tourism Management, 66, 287-301. doi:10.1016/j.tourman.2017.11.014

Sparks, B. A. (2016). Responding to negative online reviews: The effects of hotel responses on customer inferences of trust andconcern. Tourism Management, 53, 74-85.

Sparks, V. B. (2011). The impact of online reviews on hotel booking intentions and perception of trust. Tourism Management, 33, 1310-1323. doi:10.1016/j.tourman.2010.12.011

Thomas, M. B. (2018). Not just for the recommender: How eWOM incentives influence the. (Elsevier, Ed.) Journal of Business Research, 86, 11-21. doi:10.1016/j.jbusres.2018.01.041

Tijana, N. S. (2017). Inside the Rating Scores: A Multilevel Analysis of the Factors Influencing Customer Satisfaction in the Hotel Industry. Cornel Hospitality . doi:10.1177/1938965516686114

Ting, P. H., Kuo, C. F., \& Li, C.-M. (2012). What Does Hotel Website Content Say About a Property-An Evaluation of Upscale Hotels in Taiwan and China,. Journal of Travel \& Tourism Marketing, 29(4), 369-384.

Uncles, M., Dowling, G., \& Hammond, K. (2003). Customer loyalty and customer loyalty programs. Journal of Consumer Marketing, 20(4), 294-316. doi:https://doi.org/10.1108/07363760310483676

Verhoef, P. C., Reinartz, W. J., \& Krafft, M. (2010). Customer Engagement as a New Perspective in Customer Management. Journal of Service Research, 13(3), 247-252. doi:https://doi.org/10.1177/1094670510375461

Vincent, C. (2003). Internet usage by international travellers: reasons and barriers. International Journal of Contemporary Hospitality Management, 370-178. 15(7), doi: https://doi.org/10.1108/09596110310496015

VNA. (2018, July 7). Foreign tourism to Vietnam surges. Retrieved October 16, 2018, from Vietnam Investment Review: https://www.vir.com.vn/foreign-tourism-to-vietnam-surges-60796.html

Wang, L., Lawa, R., Guillet, B. D., Hung, K., \& Fong, D. K. (2015). Impact of hotel website quality on online booking intentions: eTrust as a mediator. International Journal of Hospitality Management, 47, $108-115$. doi:10.1016/j.ijhm.2015.03.012

Wang, Y. D., \& Emurian, H. H. (2005). An overview of online trust: concepts, elements and implications. Computers in Human Behavior, 21, 105-125.

Weber, et al. (2005). An Investigation of Satisfaction and Loyalty in the Virtual Hospitality Environment. Information and Communication Technologies in Tourism, 452-462. doi:10.1007/3-211-27283-6 41

Wei Wei, L. M. (2013). Customer engagement behaviors and hotel responses. International Journal of Hospitality Management, 33, 316-330. doi:10.1016/j.ijhm.2012.10.002

Wen, I. (2010). Online travelers' decision makings: a new equation model to evaluate impacts of website, search intention, and trust. Information Technology \& Tourism, 12(2), 153-173.

Xiang, Z., \& Gretzel, U. (2010). Role of social media in online travel information search. (Elsevier, Ed.) Tourism Management, 179-188. doi:10.1016/j.tourman.2009.02.016

Xiaolong, L. L. (2013). Optimal pricing strategy based on market segmentation for service products using online reservation systems: An application to hotel rooms. International Journal of Hospitality Management, 35, 274-281. doi:10.1016/j.ijhm.2013.07.001

Yeung, T. A., \& Law, R. (2006). Evaluation of Usability: A Study of Hotel Web Sites in Hong Kong. Journal of Hospitality \& Tourism Research, 30, 452-473. doi:https://doi.org/10.1177/1096348006290115

Yeung, T., \& Law, R. (2004). Extending the modified heuristic usability evaluation technique to chain and independent hotel websites. International Journal of Hospitality Management, 23(3), 307-313.

Yoon, S. (2002). The antecedents and consequences of trust in online-purchase decisions. Journal of Interactive Marketing, 16(2), 47-63.

Zeithaml, V., Parasuraman, A., \& L.L.Berry. (1990). Delivering quality service: Balancing customer perceptions and expectations. New York, USA: The Free Press.

Zeng, L. P. (2012). User-based assessment of websitecreativity: a review and appraisal. Behav. Inform. Technol., 31(4), 383-400.

Zhao, Y., Xu, X., \& Wang, M. (2018). Predicting overall customer satisfaction: Big data evidence from hotel online. International Journal of Hospitality Management, 111-121. doi:10.1016/j.ijhm.2018.03.017 
Zucker, L. (1986). Production of trust: institutional sources of economic structure. Research in Organizational

$\begin{array}{rr}1 & \text { Zucker, L. (1986). Produc } \\ 2 & \text { Behavior, 53-111. }\end{array}$ 